\title{
DIAGNOSTICS OF UNFIRED EARTH WITH METHYLENE BLUE TEST
}

\author{
Tereza Plaček Otcovská*, Barbora Mužíková, Pavel Padevět
}

\author{
Czech Technical University in Prague, Faculty of Civil Engineering, Department of Mechanics, Thákurova 7, \\ 16629 Prague 6, Czech Republic \\ * corresponding author: tereza.otcovska@fsv.cvut.cz
}

\begin{abstract}
Unfired earth is important historic building material. Final properties of unfired earth constructions are influenced by amount and kind of clay in earth mixtures. Methylene blue test is a method that helps determining the type and amount of clay in earth mixtures. This paper describes research focused on using methylene blue test for analysis of methylene blue dye absorption by montmorillonite clay. The first part of the paper describes principle of methylene blue test and course of experimental measurement. The second part deals with analysis of obtained results. On the basis of experimental measurement it can be stated that methylene blue test is influenced by the stirring time of earth samples with methylene blue solution and dependence between amount of methylene blue dye absorption and amount of montmorillonite clay in earth samples is linear.
\end{abstract}

Keywords: Clay, montmorillonite, methylene blue test, methylene blue dye, absorption, methylene blue solution.

\section{INTRODUCTION}

Unfired earth is important historic building material and nowadays unfired earth obtained its importance too. There are a lot of historic and modern buildings from unfired earth, e.g. The Great Wall of China or Berlin's Rammed-Earth Reconciliation chapel. Positive properties of unfired earth are especially that fit into principles of a sustainable building and improving of micro-climate in interiors. There is increasing interest in this building material. Therefore companies include unfired earth in their product range [1 [5].

Unfired earth is created from earth mixtures and earth mixtures are created from three basic components: sand, clay, mixing water. Final properties of unfired earth are greatly influenced by amount and kind of basic components. This composition of earth is very various in nature. This is the main reason why using of unfired earth in construction is complicated. Especially kind and amount of clay is significant because clay fulfils a function of binder, similarly like cement in concrete [4, 6, 8].

Ability to determine amount and type of clay in earth mixtures could help solve problem with various composition of earth. Methylene blue test is a method that could help determine the type and amount of clay in earth mixtures [9, 10].

The main idea of our research is that every kind of clay has different ability to absorb the methylene blue dye. If the absorbtion ability of different types of clay could be determined, it would be possible, for example in combination with geological maps, to determine the amount or type of clay in unknown earth. The basic step in this research is to determine methodology of methylene blue test for earth and then determine dye absorption capacity of individual kinds of clay.
Montmorillonite clay is a basic kind of clay and it is a common component of earth. Experimental measurement described in this paper is focused on ability of methylene blue dye absorption by montmorillonite clay.

\section{Principle of Methylene Blue TEST}

Principle of methylene blue test is absorption of methylene blue dye (methylthioninium chloride $\mathrm{C}_{16} \mathrm{H}_{18} \mathrm{ClN} \mathrm{N}_{3} \mathrm{~S}$ ) by clay. This experimental method is described for testing of aggregate's geometry in standard ČSN EN 933-9 [9] but procedure of this experiment for unfired earth testing was necessary to modify because there are much more clay types in common earth.

Methylene blue solution (MB solution) of concentration $20 \mathrm{~g} / \mathrm{l}$ is created from methylene blue dye (Fig. 1) and distilled water. Examined earth sample is created form earth mixture (sand and clay) and distilled water. Methylene blue dye and earth sample are dried in a dryer at $95^{\circ} \mathrm{C}$ for reached of equilibrium moisture.

$\mathrm{MB}$ solution is inserted into earth sample by burette (Fig. 2). MB dye absorption by earth samples is investigated.

Amount of one dose of methylene blue solution into earth sample is different. The added dye solution in earth sample is stirred for 1 minute for every added 1 $\mathrm{ml}$ of MB solution. Time for stirring of earth samples with MB solution is very important. You can see in chapter 3 that shorter stirring time distorts obtained results.

After mixing of earth sample with MB solution dose, a drop of earth sample is placed on a filter pa- 


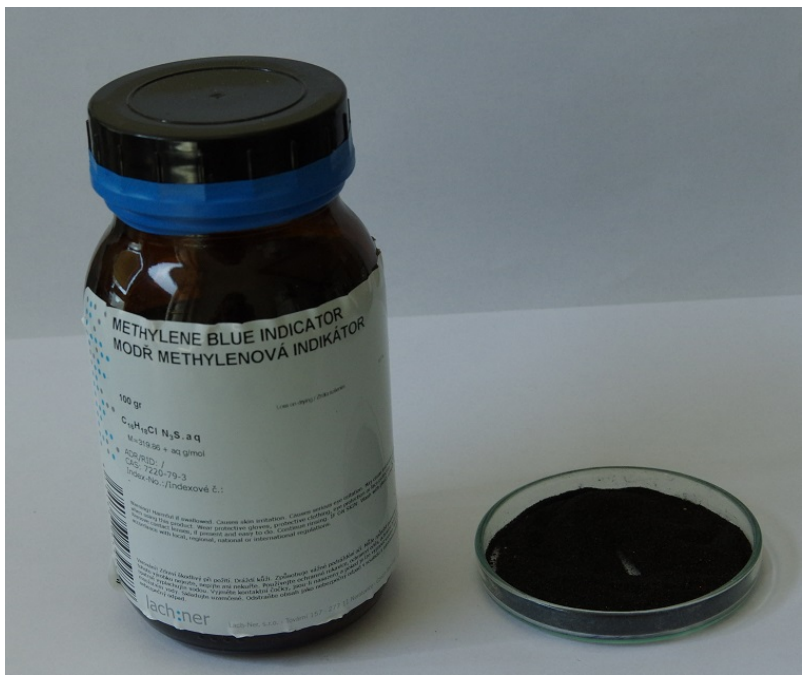

Figure 1. Methylene blue dye.

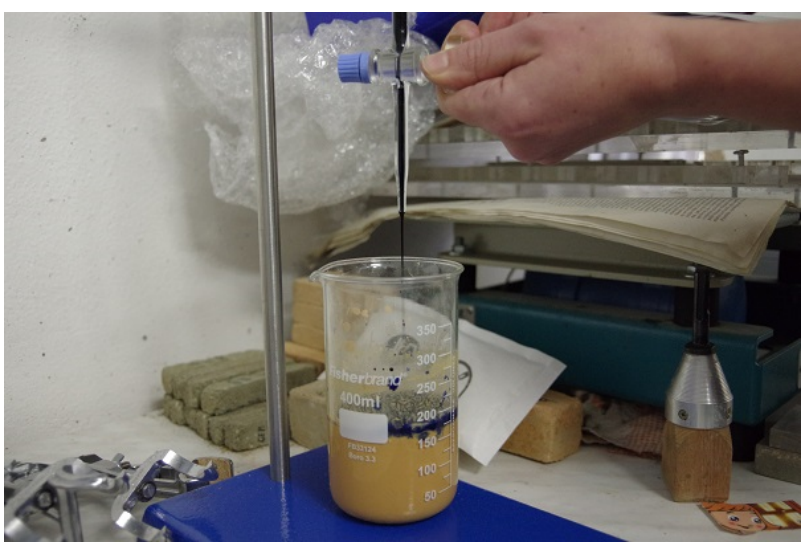

Figure 2. Methylene blue dye is dosed into earth sample.

per. Weight $87 \mathrm{~g} / \mathrm{m}^{2}$ of filter paper is used. This process is repeated and each sample drop with increasing amount of methylene blue solution is marked (Fig. 3). Methylene blue test is finished when a blue ring spreads around a drop of sample (Fig. 4) because clay has already absorbed the maximum amount of methylene blue dye.

Result of methylene blue test depends on the kind of clay in earth samples and amount of clay in earth samples. Dye solution consumption increases with increasing amount of clay in clay samples. Amount of MB dye absorbed is what we investigate.

Amount of MB dye absorbed is determined by the Equation 1 Amount of dye absorbed is defined as the amount of weight of dye in gram that is absorbed by 1 kilogram of test material.

$$
M_{M B}=\frac{m_{s} \cdot m_{M B, 1 m l} \cdot 1000}{M_{E S}}
$$

$M_{M B}$ - Amount of MB dye absorbed $[\mathrm{g} / \mathrm{kg}]$, $m_{s}$ - Amount of methylene blue solution [g],

$m_{M B, 1 m l}$ - Amount of methylene blue in $1 \mathrm{~g}$ of methylene blue solution $[\mathrm{g} / \mathrm{g}]$,

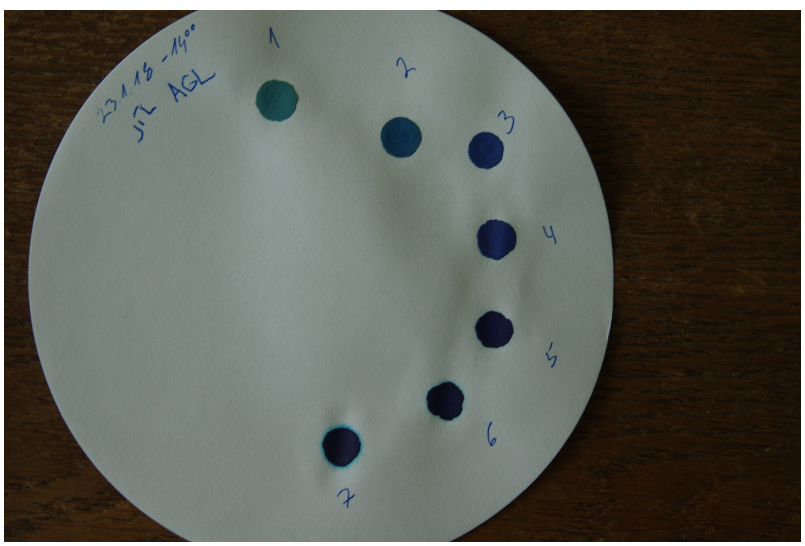

FIGURE 3. Drops of earth samples on a filter paper.

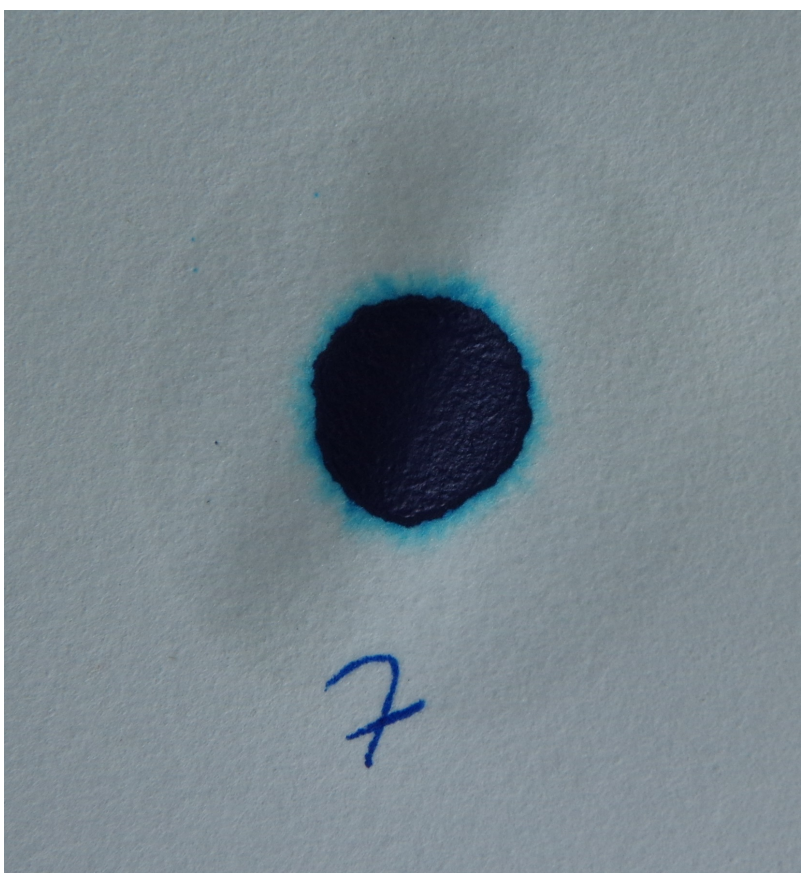

Figure 4. A blue ring around a drop of sample.

$M_{E S}$ - Amount of tested material [g].

\section{Description of Methylene blue} TEST WITH MONTMORILLONITE CLAY

This paper is focused on investigation of earth with montmorillonite clay by methylene blue test. Earth samples are created from montmorillonite clay (Fig. 5), sand and distilled water. A grain curve of sand is shown in Figure 6. Sand and montmorillonite clay were dried in dryer before production of earth samples.

There are two similar experimental measurements with the same earth samples but different stirring time of earth samples with MB solution. Different results from methylene blue test are due to different stirring time.

Composition of tested earth samples for the measurement where stirring time 1 minute is used for each $1 \mathrm{ml}$ of $\mathrm{MB}$ solution in earth samples is shown in 


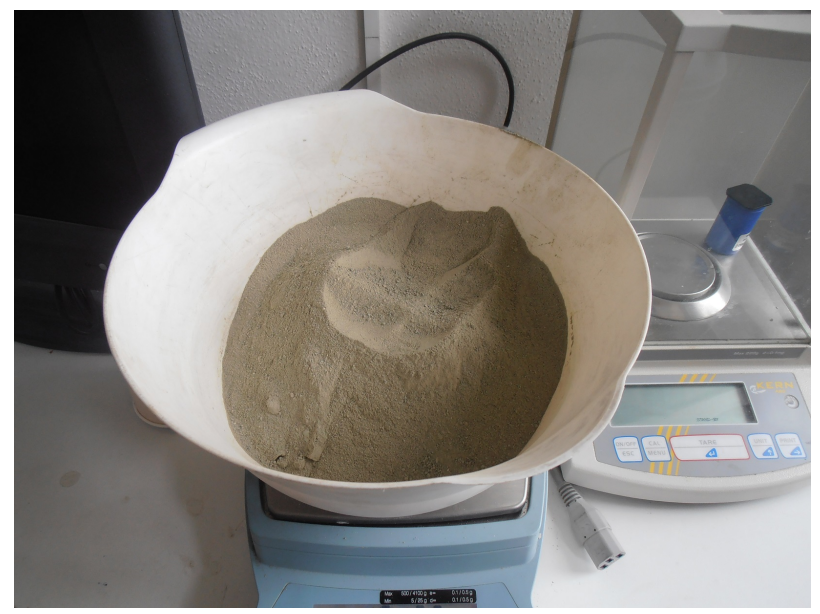

Figure 5. Montmorillonite clay.

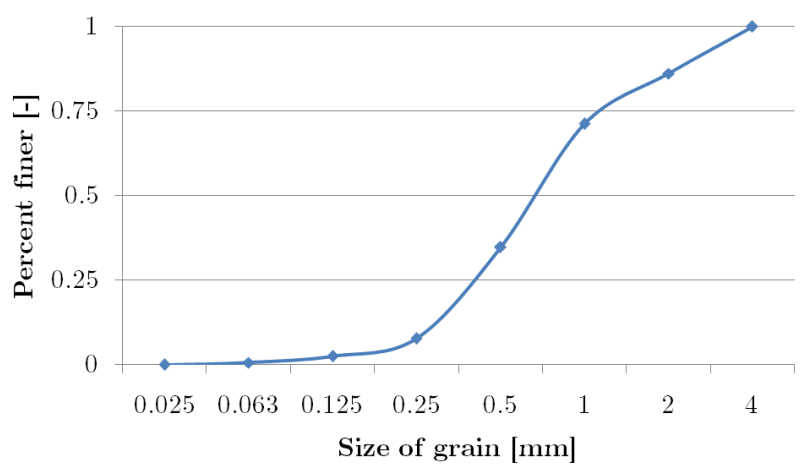

FiguRE 6. Grain curve of sand.

Table 1 (earth samples $G E M_{11}, G E M_{12}, G E M_{13}$ ).

Composition of tested earth samples for the measurement where shorter and undefined stirring time is used than 1 minute for each $1 \mathrm{ml}$ of MB solution in earth samples is shown in Table 2 (earth samples $\left.G E M_{22}, G E M_{23}\right)$.

Different sand and clay ratios are used for this experimental measurements. Amount of distilled water is same for all measurements.

Dosing of MB solution to earth samples is different for individual earth samples. MB solution is dosed to earth samples in several steps. Concrete amount of dye dose for each earth sample is shown in Table 3 for experimental measurement where 1 minute stirring time is kept. One earth sample is used for each sand and clay ratio.

Concrete amount of dye dose for each earth sample is shown in Table 4 for experimental measurement where is stirring time shorter then 1 minute for each millilitre of MB solution in an earth sample. In addition to this, no stirring time rules are followed for this experiment. Three earth samples are used for each sand and clay ratio.

Based on the values obtained and shown in Table 4 it is evident that the non-observance of stirring time has substantially affects at amount of MB dye absorption.

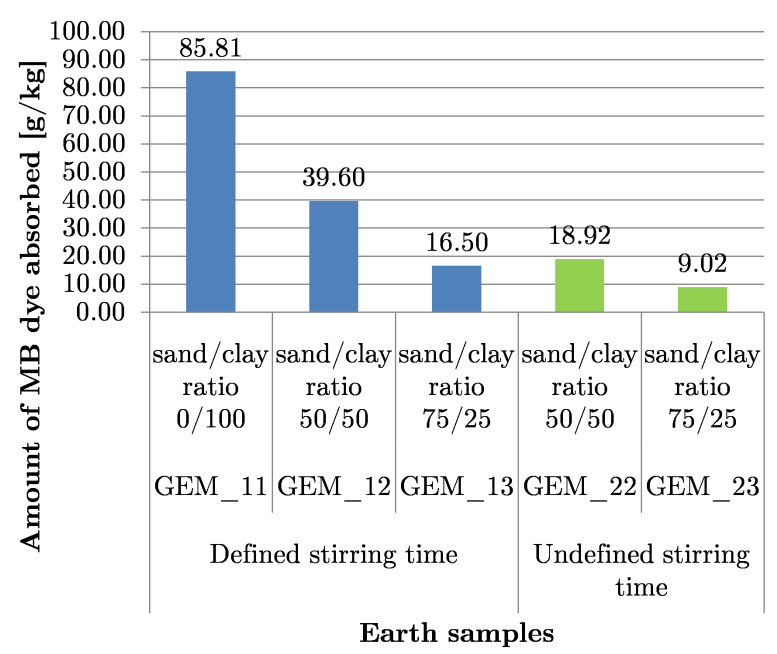

Figure 7. Resulting values of amount of MB solution absorbed.

\section{Measured Results}

Earth samples $G E M_{11}, G E M_{12}$ and $G E M_{13}$ are used for experimental measurement with defined stirring time. Earth samples $G E M_{22}$ and $G E M_{23}$ are used for experimental measurement without defined stirring time.

Amount of MB dye absorbed are calculated by Equation 1 from obtained values showed in Tables 3 and 4 . Amount of MB dye absorbed is shown in Tables 5 and 6 . Average values of results from calculated values is shown in Table 7

All resulting values of amount of MB dye absorbed are shown in Fig. 7. Obviously, significantly greater amounts of MB dye absorbed are in earth samples where stirring time was maintained. Difference between amount of MB dye absorbed with and without defined stirring time is approximately $50 \%$ (see Table 8). Therefore, we can assume that stirring time has significant impact on amount of BM dye absorbed and it is necessary to define it.

Methylene blue test without defined stirring time seems to have negligible informative value. Therefore, in following part attention is devoted to results from measurement with defined stirring time.

\subsection{Methylene Blue Test with Defined StirRing Time}

There are hypothesis that dependency between amount of clay in earth samples and amount of MB dye absorbed is linear.

Three types of earth samples are tested by methylene blue test with defined stirring time $\left(G E M_{11}\right.$, $\left.G E M_{12}, G E M_{13}\right)$. Only one test sample of each type of earth samples is created.

Amount of $\mathrm{MB}$ dye absorbed in $G E M_{11}$ earth sample is $85.81 \mathrm{~g} / \mathrm{kg}$, in $G E M_{12}$ earth sample is $39.60 \mathrm{~g} / \mathrm{kg}$ and in $G E M_{13}$ earth sample is $16.50 \mathrm{~g} / \mathrm{kg}$ (see Table 5). Dependence between amount of clay and amount of MB dye absorbed is demonstrated in Fig. 8. 


\begin{tabular}{cccccc}
\hline $\begin{array}{c}\text { Mark of } \\
\text { sample }\end{array}$ & Kind of clay & $\begin{array}{c}\text { Sand/clay } \\
\text { ratio } \\
{[\% / \%]}\end{array}$ & $\begin{array}{c}\text { Amount of } \\
\text { clay [g] }\end{array}$ & $\begin{array}{c}\text { Amount of } \\
\text { sand [g] }\end{array}$ & $\begin{array}{c}\text { Amount of } \\
\text { distilled water [g] }\end{array}$ \\
\hline$G E M_{11}$ & montmorillonite & $0 / 100$ & 15 & 0 & 75 \\
$G E M_{12}$ & montmorillonite & $50 / 50$ & 7.5 & 7.5 & 75 \\
$G E M_{13}$ & montmorillonite & $75 / 25$ & 3.75 & 11.25 & 75 \\
\hline
\end{tabular}

TABLE 1. Composition of earth samples for the measurement where stirring time 1 minute is used for each $1 \mathrm{ml}$ of MB solution in earth samples.

\begin{tabular}{cccccc}
\hline $\begin{array}{c}\text { Mark of } \\
\text { sample }\end{array}$ & Kind of clay & $\begin{array}{c}\text { Sand/clay } \\
\text { ratio } \\
{[\% / \%]}\end{array}$ & $\begin{array}{c}\text { Amount of } \\
\text { clay [g] }\end{array}$ & $\begin{array}{c}\text { Amount of } \\
\text { sand [g] }\end{array}$ & $\begin{array}{c}\text { Amount of } \\
\text { distilled water [g] }\end{array}$ \\
\hline$G E M_{22}$ & montmorillonite & $50 / 50$ & 7.5 & 7.5 & 75 \\
$G E M_{23}$ & montmorillonite & $75 / 25$ & 3.75 & 11.25 & 75 \\
\hline
\end{tabular}

TABLE 2. Composition of earth samples for the measurement where shorter stirring time then 1 minute is used for each $1 \mathrm{ml}$ of $\mathrm{MB}$ solution in earth samples.

\begin{tabular}{|c|c|c|c|c|c|c|c|c|c|c|c|c|c|c|c|c|c|}
\hline \multirow[b]{2}{*}{$\begin{array}{l}\text { Mark of } \\
\text { sample }\end{array}$} & & \multicolumn{16}{|c|}{ Number of dose } \\
\hline & & 1 & 2 & 3 & 4 & 5 & $\ldots$ & 9 & 10 & 11 & $\ldots$ & 14 & 15 & 16 & 17 & 18 & 19 \\
\hline$G E M_{11}$ & $\begin{array}{c}\text { Visibility of } \\
\text { blue ring }\end{array}$ & no & no & no & no & no & $\ldots$ & no & no & no & $\ldots$ & no & no & no & no & no & yes \\
\hline $\begin{array}{l}\text { sand/clay } \\
\text { ratio } \\
0 / 100\end{array}$ & $\begin{array}{c}\text { Amount of } \\
\text { MB } \\
\text { solution } \\
{[\mathrm{ml}]}\end{array}$ & 5 & 5 & 5 & 5 & 2 & $\ldots$ & 2 & 15 & 5 & $\ldots$ & 5 & 10 & 15 & 15 & 15 & 10 \\
\hline & Total amount & of & MB & luti & 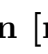 & & & & & & & & & & & & 130 \\
\hline$G E M_{12}$ & $\begin{array}{c}\text { Visibility of } \\
\text { blue ring }\end{array}$ & no & no & yes & & & & & & & & & & & & & \\
\hline $\begin{array}{l}\text { sand/clay } \\
\text { ratio } \\
50 / 50\end{array}$ & $\begin{array}{c}\text { Amount of } \\
\text { MB } \\
\text { solution } \\
{[\mathrm{ml}]}\end{array}$ & 40 & 10 & 10 & & & & & & & & & & & & & \\
\hline & Total amount & of & $\mathrm{BB}$ & luti & r. & & & & & & & & & & & & 60 \\
\hline$G E M_{13}$ & $\begin{array}{l}\text { Visibility of } \\
\text { blue ring }\end{array}$ & no & yes & & & & & & & & & & & & & & \\
\hline $\begin{array}{l}\text { sand/clay } \\
\text { ratio } \\
75 / 25\end{array}$ & $\begin{array}{c}\text { Amount of } \\
\text { MB } \\
\text { solution } \\
{[\mathrm{ml}]}\end{array}$ & 20 & 5 & & & & & & & & & & & & & & \\
\hline & Total amount & of & {$[\mathrm{B}$} & luti & [ & & & & & & & & & & & & 25 \\
\hline
\end{tabular}

TABLE 3. Doses of methylene blue solution to GEM earth sample where stirring time 1 minute is used for each $1 \mathrm{ml}$ of MB solution in earth samples. 


\begin{tabular}{|c|c|c|c|c|c|c|c|c|}
\hline \multirow[b]{2}{*}{$\begin{array}{l}\text { Mark of } \\
\text { sample }\end{array}$} & \multirow[b]{2}{*}{ Measurement no. } & \multicolumn{7}{|c|}{ Number of dose } \\
\hline & & & 1 & 2 & 3 & 4 & 5 & 6 \\
\hline$G E M_{22}$ & first & Visibility of blue ring & no & no & no & no & no & yes \\
\hline sand/clay & measurement & Amount of MB solution $[\mathrm{ml}]$ & 10 & 4 & 4 & 4 & 4 & 2 \\
\hline ratio $50 / 50$ & & Total amount of MB solution & {$[\mathrm{ml}]$} & & & & & 28 \\
\hline$G E M_{22}$ & second & Visibility of blue ring & no & no & no & no & yes & \\
\hline sand/clay & measurement & Amount of MB solution $[\mathrm{ml}]$ & 15 & 5 & 5 & 3 & 2 & \\
\hline ratio $50 / 50$ & & Total amount of MB solution & {$[\mathrm{ml}]$} & & & & & 30 \\
\hline$G E M_{22}$ & third & Visibility of blue ring & no & no & no & yes & & \\
\hline sand/clay & measurement & Amount of MB solution $[\mathrm{ml}]$ & 15 & 5 & 5 & 3 & & \\
\hline ratio $50 / 50$ & & Total amount of MB solution & {$[\mathrm{ml}]$} & & & & & 28 \\
\hline$G E M_{23}$ & first & Visibility of blue ring & yes & & & & & \\
\hline sand/clay & measurement & Amount of MB solution [ml] & 15 & & & & & \\
\hline ratio $75 / 25$ & & Total amount of MB solution & {$[\mathrm{ml}]$} & & & & & 15 \\
\hline$G E M_{23}$ & second & Visibility of blue ring & no & no & no & yes & & \\
\hline sand/clay & measurement & Amount of MB solution [ml] & 5 & 2 & 3 & 3 & & \\
\hline ratio $75 / 25$ & & Total amount of MB solution & {$[\mathrm{ml}]$} & & & & & 13 \\
\hline$G E M_{23}$ & third & Visibility of blue ring & no & yes & & & & \\
\hline sand/clay & measurement & Amount of MB solution [ml] & 10 & 2 & & & & \\
\hline ratio $75 / 25$ & & Total amount of MB solution & {$[\mathrm{ml}]$} & & & & & 12 \\
\hline
\end{tabular}

TABLE 4. Doses of methylene blue solution to GEM earth sample where stirring time shorter than 1 minute is used for each $1 \mathrm{ml}$ of MB solution in earth samples .

\begin{tabular}{ccc}
\hline $\begin{array}{c}\text { Mark of } \\
\text { sample }\end{array}$ & $\begin{array}{c}\text { Sand/clay } \\
\text { ratio } \\
{[\% / \%]}\end{array}$ & $\begin{array}{c}\text { Amount of MB } \\
\text { dye absorbed } \\
{[\mathrm{g} / \mathbf{k g}]}\end{array}$ \\
\hline$G E M_{11}$ & $0 / 100$ & 85.81 \\
$G E M_{12}$ & $50 / 50$ & 39.60 \\
$G E M_{13}$ & $75 / 25$ & 16.50 \\
\hline
\end{tabular}

TABLE 5. Amount of MB dye absorbed by earth samples during methylene blue test with defined stirring time.

\begin{tabular}{ccc}
\hline $\begin{array}{c}\text { Mark of } \\
\text { sample }\end{array}$ & $\begin{array}{c}\text { Measure- } \\
\text { ment } \\
\text { no. }\end{array}$ & $\begin{array}{c}\text { Amount of MB } \\
\text { dye absorbed } \\
{[\mathbf{g} / \mathbf{k g}]}\end{array}$ \\
\hline$G E M_{22}$ & 1 & 18.48 \\
sand/clay & 2 & 19.80 \\
ratio $50 / 50$ & 3 & 18.48 \\
$G E M_{23}$ & 1 & 9.90 \\
sand/clay & 2 & 8.58 \\
ratio $75 / 25$ & 3 & 8.58 \\
\hline
\end{tabular}

TABLE 6. Amount of MB dye absorbed by earth samples during methylene blue test without defined stirring time.

It can be seen from Fig. 8 that the hypothesis could be correct.

\begin{tabular}{cccc}
\hline $\begin{array}{c}\text { Mark of } \\
\text { sample }\end{array}$ & $\begin{array}{c}\text { Sand/clay } \\
\text { ratio } \\
{[\% / \%]}\end{array}$ & $\begin{array}{c}\text { amount of } \\
\text { MB dye } \\
\text { absorbed } \\
{[\mathrm{g} / \mathbf{k g}]}\end{array}$ & $\begin{array}{c}\text { Standard } \\
\text { deviation } \\
{[\mathrm{g} / \mathrm{kg}]}\end{array}$ \\
\hline$G E M_{22}$ & $50 / 50$ & 18.92 & 0.62 \\
$G E M_{23}$ & $75 / 25$ & 9.02 & 0.62 \\
\hline
\end{tabular}

TABLE 7. Average values of amount of MB dye from methylene blue test without defined stirring time.

\section{Conclusion}

Methylene blue test could be useful tool for identification of composition of unknown earth. Our experiments show that it is important to maintain observed and uniform approach of methylene blue test, especially the stirring time (see Fig. 7).

Next important point is that dependence between amount of MB solution absorbed and amount of clay in earth samples seems to be linear (see Fig. 8). However, these conclusions of our work need to be verified by further experimental measurements because we tested only one type of clay and we used only one earth sample for every amount of clay in the earth sample.

\section{LIST OF SYMBOLS}

$M B$ Methylene blue

$M_{M B} \quad$ Amount of MB dye absorbed $[\mathrm{g} / \mathrm{kg}$ ]

$m_{s}$ Amount of methylene blue solution [g] 


\begin{tabular}{|c|c|c|c|c|}
\hline \multirow{4}{*}{$\begin{array}{l}\text { Mark of sample } \\
\text { Amount of MB dye absorbed }[\mathrm{g} / \mathrm{kg}] \\
\text { Difference between amount of } \mathrm{MB} \text { dye absorbed [\%] }\end{array}$} & \multicolumn{2}{|c|}{$\begin{array}{c}\text { Sand clay ratio } \\
50 / 50[\% / \%]\end{array}$} & \multicolumn{2}{|c|}{$\begin{array}{c}\text { Sand clay ratio } \\
75 / 25[\% / \%]\end{array}$} \\
\hline & $G E M_{12}$ & $G E M_{22}$ & $G E M_{13}$ & $G E M_{23}$ \\
\hline & 39.60 & 18.92 & 16.50 & 9.02 \\
\hline & \multicolumn{2}{|c|}{52.22} & $(100 \%=$ & $\begin{array}{l}33 \\
.50 \mathrm{~g} / \mathrm{kg})\end{array}$ \\
\hline
\end{tabular}

TABLE 8. Difference between amount of MB dye absorbed with and without defined stirring time $\left(G E M_{12}, G E M_{13}\right.$ defined stirring time; $G E M_{22}, G E M_{23}$ - undefined stirring time).

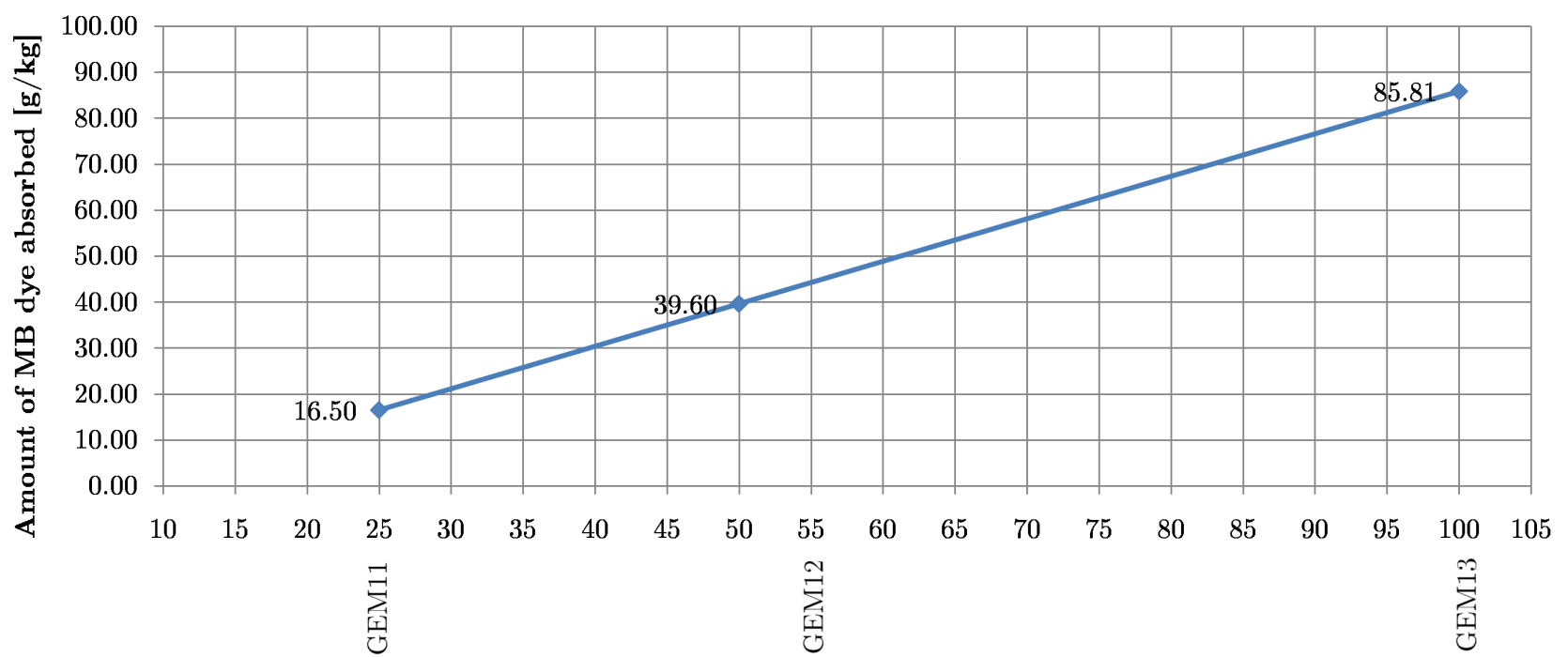

Amount of clay [\%]

FiguRE 8. Dependence between amount of clay in earth samples and amount of MB dye absorbed.

$m_{M B, 1 m l}$ Amount of methylene blue in $1 \mathrm{~g}$ of methylene blue solution $[\mathrm{g} / \mathrm{g}]$

$M_{E S} \quad$ Amount of tested material [g]

\section{ACKNOWLEDGEMENTS}

The financial support of this experiment by the Czech Science Foundation (GAČR project NO. 18-10884S) and Faculty of Civil Engineering, Czech Technical University in Prague (SGS project No. SGS16/201/OHK1/3T/11) is gratefully acknowledged. We would like to express our thanks to LB MINERALS, s.r.o. company for free supply of material necessary for experimental measurement.

\section{REFERENCES}

[1] P. Jaquin, C. Augarde. Earth building : History, science and conservation. Report, Bracknell : IHS BRE Press, 2012.

[2] Agenda 21 - United Nations Environment Programme (UNEP). http://www . unep.org/Documents . Multilingual/Default . asp?documentid=52

[3] A. Jing. A History of the Great Wall of China. World Scientific Publishing Company, 2015.
[4] G. Minke. Building With Earth. Ökobuch Verlag, Staufen.

[5] P. Stejskal. E-mail consultation with Heluz company, 2017.

[6] I. Žabičková. Hliněné stavby. Era 21, Brno, 2002.

[7] P. Walker. Rammed Earth: Design and Construction Guidelines. IHS BRE Press, Watford, 2010.

[8] Z. Weiss. Jílové Minerály : Jejich Nanostruktura a Využití. Karolinum,, vyd. 1. edn., 2005.

[9] Evropský výbor pro normalizaci. ČSN EN 933-9, Zkoušení geometrických vlastností kameniva - Část 9: Posouzení jemných částic - Zkouška methylenovou modří, 2013.

[10] Y. Yeliz, K. Abidin. Suitability of the methylene blue test for surface area, cation exchange capacity and swell potential determination of clay soils. Engineering Geology 2008(102):38-45, 2008. 